Anca-Simina MARTIN

Faculty of Letters and Arts

Sibiu, Romania

anca.martin@ulbsibiu.ro

\title{
A QUANTITATIVE ANALYSIS OF THE ROMANIAN TRANSLATIONS OF SHAKESPEARE'S BAWDY PUNS
}

Recommended Citation: Martin, Anca-Simina. "A Quantitative Analysis of the Romanian Translations of Shakespeare's Bawdy Puns”. Metacritic Journal for Comparative Studies and Theory 6.2 (2020):

https://doi.org/10.24193/mjcst.2020.10.04.

\begin{abstract}
:
This article proposes a quantitative analysis of the Romanian translations of 325 ribald Shakespearean puns, which originate in 20 plays and 71 renditions, with special focus on assessing the impact of translator-subjective and objective factors on the rendition process in the pre-communist, communist, and post-communist periods. The findings invalidate several widespread beliefs: Dragoş Protopopescu's renditions, banned by the communist regime for their 'modernizing' approach to the Shakespearean text, bowdlerized more bawdy puns than 'ESPLA', which replaced it as the Party-approved Romanian edition of the dramatist's plays; Adolphe Stern's translations, harshly criticized in his period, fare better in terms of ribald pun rendition than Scarlat Ghica's and Dimitrie Ghica's, hailed as the most successful of their time; modern translations of Shakespeare display a heterogeneous distribution of target-text puns across the surveyed rendition strategies, despite enjoying similar availability of and access to pun translation studies.
\end{abstract}

Keywords: pun, quantitative research, Romanian translation, Shakespeare, wordplay.

The translation of Shakespearean bawdy wordplay has, for the most part, been the subject of qualitative research, in Romania as well as abroad. With the exception of 
studies such as Magdalena Krawiec's (2017) analysis of the frequency of pun rendition strategies in the Polish translations of Love's Labour's Lost, the quantitative approach to the playwright's puns and ribald language-play in particular is hardly a popular avenue of research among scholars of Shakespeare translation, with the relevance-theoretic approach proposed by Francisco Díaz-Pérez (2013) constituting the most widely used framework in Shakespearean translation studies. Recently, Eriko Sato (2019) has successfully deployed a translanguaging-based model, yet in her case, like in Krawiec's and Díaz-Pérez's, the corpus is limited to a low number of puns and translations.

One important factor is responsible for the relative absence of quantitative approaches to this aspect of Shakespeare's language: the lack of a methodological framework developed to this end. This article proposes a quantitative analysis of the translation of 325 unanimously accepted ribald puns originating in 20 Shakespearean plays and 71 Romanian renditions, with special focus on assessing the impact of translator-subjective and objective factors on the translation of the dramatist's bawdy wordplay in the pre-communist, communist, and post-communist eras. In this respect, I will use a modified wordplay rendition methodology, which draws on Dirk Delabastita's (1993) competence model and Díaz-Pérez's cognitivepragmatic reworking (2015), and associates the various approaches to pun translation with specific rendition strategies.

It is only rarely and of fairly recent date that quantitative analyses of Shakespeare's bawdy wordplay have been attempted in Romania. In 2003, Romanian Shakespeare scholar and translator George Volceanov delivered a paper in Utrecht, revealing the findings of his comparative analysis of 306 ribald words and phrases singled out arbitrarily from 29 plays and two poems translated into Romanian during the communist regime. He counted 179 instances of meaning-formeaning translation, 93 cases of lost bawdy connotations, and 34 situations in which the translators appear to have surpassed the ingenuity of the source text (Volceanov, "Bowdlerizing" 120). The study per se has not been published of late, but its results and the critical materials deployed in the compilation of the corpus have been mentioned in several of Volceanov's articles (2006; 2012). There, the scholar indicates that he selected the bawdy expressions based on Eric Partridge's Shakespeare's Bawdy (1947). Yet this glossary of Shakespearean ribaldry brings together non-punning ribald words and bawdy puns. 
Since the previously mentioned articles do not provide a detailed account of the corpus, it is difficult to say whether Volceanov's inquiry includes language-play or is limited to studying bawdy words. A set of legitimate questions then arise: if his analysis includes puns, what does sense-for-sense imply in that case? If some words lose their ribald connotations, does this indicate that those instances of bawdy constitute plays on two meanings, ribald and non-ribald, of the same word? Indeed, the results of his statistical inquiry are provocative: according to Volceanov, $70 \%$ of the surveyed sample was rendered effectively into Romanian, yet to what extent is this the outcome of a methodology-based research or the empiric estimations of a Shakespeare translator? My thesis is that only a survey based on a quantitative studies-oriented framework can answer this question.

\section{Considerations on the methodology}

In consulting Frankie Rubinstein's 1984 Dictionary of Shakespeare's Sexual Puns and Their Significance, the latest of this kind to be printed to date, by far the lengthiest, and theoretically the most suitable to my purpose, "one has to ask oneself who is making the pun: the author (through the character), or the interpreter" (Wells 27). Stanley Wells' perspective is reinforced by Delabastita's practical observations on the serviceability of such dictionaries. In reference to Rubinstein's, he notes, "it hardly needs pointing out that not a trace of these more adventurous interpretations can be found in any of the translations I looked into" (309). Despite their uncontested merits, evidenced by their being referenced in the commentaries of reputable editions of Shakespeare's works, such glossaries constitute, on many occasions, exaggerations of either a deliberate or involuntary nature. As a result, the compilation of my corpus drew primarily on the annotations provided in critical editions of Shakespeare. In this respect, the RSC [Royal Shakespeare Company] series proved the most helpful: unlike New Cambridge, Oxford and Arden, this collection is edited by two scholars only, Eric Rasmussen and Jonathan Bate, and is thus consistent throughout all the plays in terms of annotation style.

After identifying the most reliable source-text puns, their Romanian targetlanguage counterparts were grouped into six wordplay translation strategies according to a simplified version of the competence model Dirk Delabastita put forward and Díaz-Pérez reworked: Díaz-Pérez's PUNNING CORRESPONDENCE, which entails the punning reproduction of the source-text wordplay, was split into 
PUN > INNOCENT PUN [P > P (I)] and PUN > BAWDY PUN [P > P (B)], in order to differentiate between the translators that have recreated the language-play and preserved or lost the ribald substratum. It should be noted that, in these categories, I also include what Delabastita calls ZERO > PUN and NON-PUN > PUN, as although the source-text pun plays on material added by the translator or on a source-text non-punning word, these two translation solutions exhibit an awareness of the language-play and a deliberate attempt to recapture it in the target text. Delabastita's PUN > NON-PUN, whereby the source-text pun is replaced by a target-language word that does not preserve the language-play, was divided into PUN > INNOCENT NON-PUN [P > N-P (I)] and PUN > BAWDY NON-PUN [P > N-P (B)], which indicate that the translator was either unaware of or glossed over the double meaning. OTHER subsumes a wider array of compensatory solutions which preserve either the cultural scenario, the pragmatic or neither of the two - TRANSFERENCE, DIRECT TRANSFER, DIFFUSE PARAPHRASE, PUNOID, and EDITORIAL TECHNIQUES. I resorted to this reduction because all of these translation strategies are indicative of efforts to recuperate the pun and/or bawdy substratum, either by grafting source-language senses onto target-language words, recreating the semantics of the original pun, substituting the wordplay with a related stylistic device, or explaining it via a translator's note. The only one of Delabastita's translation methods to be borrowed in an unmodified form is PUN > ZERO [P > ZERO] - OMISSION in Díaz-Pérez's framework -, whereby the translator omits to render an instance of wordplay, either out of incognizance or intended expurgation so as to comply with societal expectations or ideological restrictions.

\section{A quantitative analysis of bawdy wordplay translations in Hamlet}

In the pursuit of providing a statistical perspective of bawdy wordplay translation in Shakespeare's works, I have opted to chart the phenomenon from the particular to the general. In so doing, the play that can, in theory, offer the most relevant insight in this respect is Hamlet, perhaps one of the most recognizable Shakespearean plays and undoubtedly his most frequently translated into Romanian. The corpus of puns identified in this play amount to 12 instances, whose dispersal across the six rendition strategies is displayed in Figure 1. 


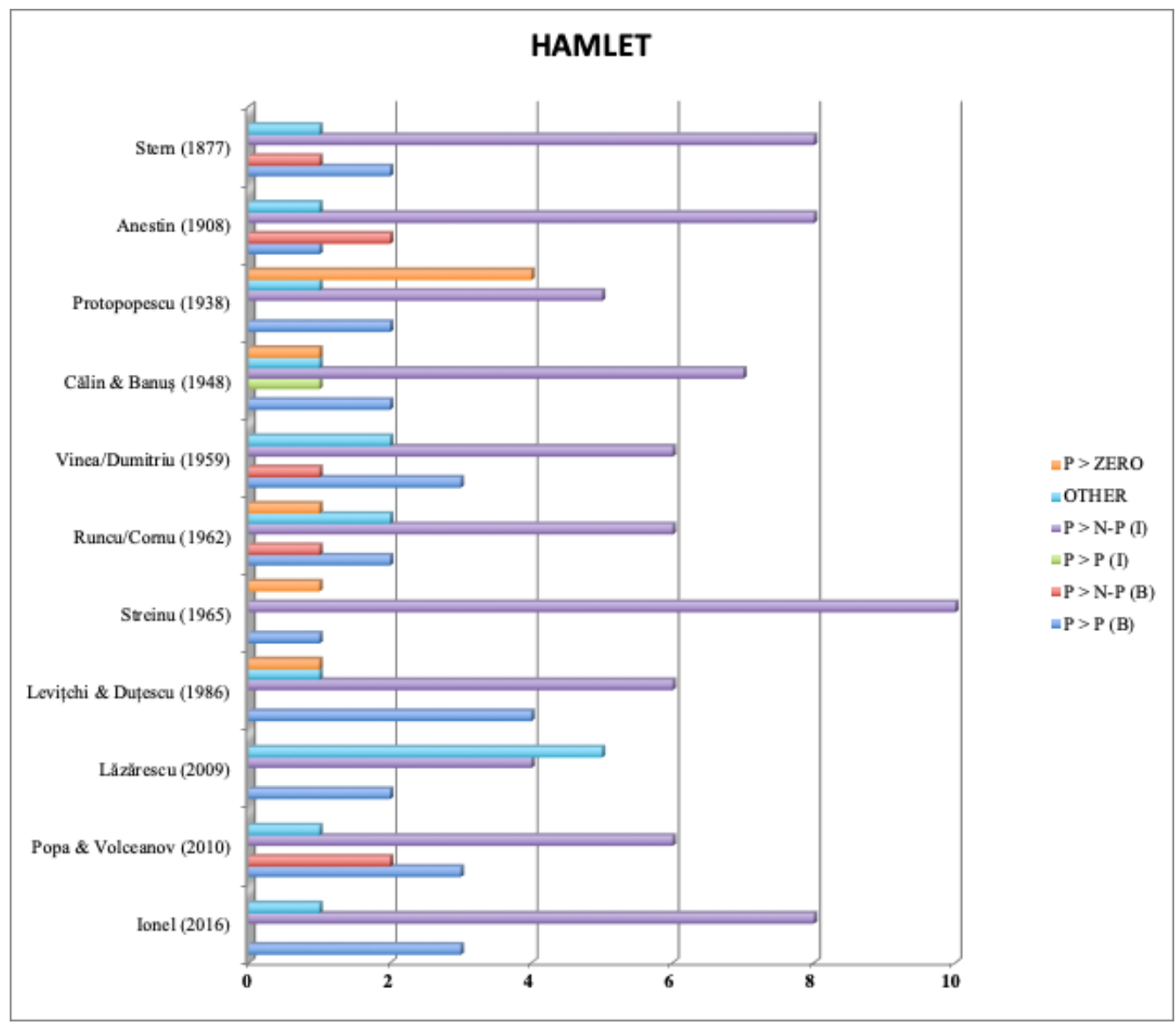

Figure 1. The translation strategies deployed in the eleven Romanian renditions of Hamlet

Although separated by more than a quarter of a century, Stern's and Anestin's renditions do not appear to indicate major shifts in translational approach to the playwright's ribald puns, which is indicative of their belonging to the same translational mentality/system, which extends from the earliest Shakespearean translations to World War I. Indeed, Stern's rendition features a higher incidence of bawdy puns translated effectively both in terms of language-play and suggestiveness [see P > P (B)]. This may be due to subjective factors such as, perhaps, his lack of prudishness; take, for instance, Guildenstern's pun on 'privates', which plays on 'soldiers' and 'genitals' (Ham. 2.2.244). Anestin translates it as 'protejaţi' ('protégés') (88), while Stern opts for 'intimi' ('confidants') (90). As for Hamlet's ensuing comparison between Faith and a strumpet (Ham. 2.2.246), which the former renders euphemistically as 'femeie publică' ('public woman') and the latter bluntly as 'târfă' ('whore'), it is only in Stern's translation that the bawdy subtext of 'privates' is recreated through association with the adjectival meaning of 'intim'. It should, however, be noted that the two translations exhibit the same number of puns 
acknowledged by the two translators [see $\mathrm{P}>\mathrm{P}$ (B) and $\mathrm{P}>\mathrm{N}-\mathrm{P}$ (B)]. At a macro level, a lack of ideological or ethical interference in the translation process is observed, as neither one of the puns submitted for analysis is expurgated from the target text.

Compared to the two previous renditions, Dragoș Protopopescu's is a special case in that no less than four puns of the total 12 instances of wordplay are expurgated from the target text [see $\mathrm{P}>\mathrm{ZERO}$ ]. His rendition is missing, among others, Act 3 scene 2's lines 246-255, a textual fragment containing no less than three specimens of bawdy language-play between Hamlet and Ophelia. Hamlet's line 121 "That's a fair thought to lie between a maid's legs" -, whereby his pun on 'to lie' is effected, disappears from his translation, although Protopopescu's 'a se culca' ('to sleep') can potentially recreate it by itself (103). This omission, like in Anestin's case, may be attributed to the translator's relying on the First Quarto of the play, which was then commonly thought to be a memorial reconstruction of the text by a spectator of a Hamlet performance (Erne 199). Should this theory be found correct by further research, the question still remains as to the reason why the Q2 [Second Quarto] and F [Folio]'s Act 4 scene 7 appears two scenes earlier in his translation and why it does not feature said missing lines since they occur in the First Quarto, though, admittedly, not in their entirety. Therefore, as compared to Stern and Anestin, who, at the very least, rendered the wordplay non-punningly and nonbawdily, Protopopescu goes on to eliminate them and their textual fragments. This, I believe, is due to both subjective and objective factors: on the one hand, there was Nicolae Iorga's hunt for pornography in literature and on the other, Protopopescu's collaboration with royalty-owned publishing houses and his far-right political leanings against the onset of the communist regime, which led not only to his untimely demise and subsequent ban from public libraries, but also to a self-inflicted interventionist approach to the Shakespearean text.

There is reason to suspect that either self-censorship or some coercive action on the part of a regulatory body also affected other later renditions of the play. Translators and essayists Vera Călin and Maria Banuș published the first translation of Hamlet following the imposition of the socialist regime. Despite the heavily supervised backdrop against which it was produced, their rendition appears not to have suffered as much as Protopopescu's. Only one of the 12 instances of wordplay submitted for analysis disappears from their translation [see P > ZERO]. It should, 
however, be noted that Călin and Banuş's rendition exhibits no intention to preserve the bawdy substratum in the cases where the language-play could not be reproduced. A very illustrative example in this regard is their approach (121) to Hamlet's pun on 'to lie' (Ham. 3.2.115-118) which, of the surveyed 11 renditions, is the only one to qualify for the PUN > NON-PUN INNOCENT strategy. In concrete terms, Hamlet's line 115 and Ophelia's 116 vanish from their rendition, with their Hamlet failing to exhibit source-text Hamlet's impertinence. Instead, Călin and Banuş's version of the dialogue depicts the character as seeking permission to rest his head on Ophelia's lap - "îmi dai voie să-mi odihnesc capul pe genunchii tăi” - and picturing the possibility of sleeping next to a maid's thighs - "să te culci lângă coapsele unei fecioare" rather than between them, as Shakespeare's Hamlet muses (95).

In contrast, Ion Vinea appears to have gone to greater lengths to preserve not only the ribald undertones but also the language-play of the puns subjected to investigation. This achievement is all the more remarkable as his translation was published as part of the 1955-1963 Shakespeare edition, intended to take "a safe distance from Protopopescu's lively, modernizing versions," which had been banned only nine years prior within an extensive campaign to "establish 'the [party] line' ... that all critics and performers of Shakespeare were supposed to toe, unless they were willing to risk censorship" (Nicolaescu 286). The circumstances under which Vinea's Hamlet appeared were, however, significantly more complicated. At that time, the poet was no longer allowed to publish his works due to his reluctance to join the Party and in the summer of 1959, when his rendition was issued, he would be arrested for selling some two hundred gold coins to his friend Petru Dumitriu seven years earlier (Cordoș 178). Despite the uncomfortable position of the translator and the vigilant censorship apparatus, Vinea's rendition of Hamlet exhibits five more or less successful ribald pun translations [see P > P (B), P > N-P (B) and OTHER]. For instance, Ion Vinea is the first to translate Hamlet's 'favours' (Ham. 2.2.243) as 'plăceri' ('pleasures') (581), which is more readily associated with sexual indulgence than Stern and Anestin's 'favoare(oruri)' ('favour[s]') (1877: 89; 1908: 87) and Călin and Banuş's 'grații' ('graces') (68).

Initially published in 1964 in an individual volume, Dan Duțescu and Leon Levițchi's Hamlet re-emerges in the latter's 1982-1991 'Univers' edition of Shakespeare's works, which republishes many of the translations produced for Gheorghiu's earlier 1955-1963 project and, in some cases, puts forward re-renditions 
of popular plays. Produced one year before the official debut of the 'liberalization' (Terian 2013), their individually printed Hamlet "received almost no attention when released," in spite of its comprehensive critical apparatus and astute paratexts (Cinpoeș 97), which “displayed an openness towards foreign criticism” (Milică 34). In 1982, when Levițchi's 'Univers' edition debuts, the translator goes on to consolidate this new paradigm of Shakespeare, whereby he is envisioned in humanistic terms as "a dramatist-poet-thinker" (Volceanov, "Bawdy" 218). 32 This is, as Milică notes, a clear indication that the "turn towards openness starting in the middle of the 1960 s is more obvious in the 1970 s and 1980s" (33). This "prolonged liberalization' and subsequent increased access to more recent critical materials (34) appears to have also positively impacted Duțescu and Levițchi's approach to bawdy puns (Martin 2018). In concrete terms, their translation features four instances of successfully rendered wordplay in terms of both punning and bawdy, of which one does not find a punning counterpart in any of the renditions submitted for analysis [see $\mathrm{P}>\mathrm{P}$ (B)]. This is the case of Hamlet's pun on 'puppets', which plays on 'marionettes' and 'breasts' (Ham. 3.2.247-248), whose ribald substratum the cotranslators transfer onto their translation of 'dallying' as 'a se hârjoni,' which refers to frolicking and sexual petting (381).

Violeta Popa and George Volceanov's translation of the play, the first to be published in a complete edition of Shakespeare's works in more than twenty years, is a premiere in the history of Hamlet renditions into Romanian, in that it reunites in a volume the three existing versions of the text in separate translations. The translators' mission to reproduce the playwright's bawdy is very much verifiable against the instances of wordplay submitted for analysis: yoked together, the cases in which co-translators Popa and Volceanov effectively preserve the ribald connotations outnumber Duțescu and Levițchi's [see P > N-P (B), OTHER]. As for the level of success in conveying both the punningness and the bawdy undertones of the surveyed wordplay, their translation falls short of replicating Duțescu and Levițchi's achievements in this respect [see $\mathrm{P}>\mathrm{P}(\mathrm{B})$ ]. This indicates a shift in focus from recreating the bawdy language-play to emphasizing the obscene substratum.

${ }_{32}$ "Shakespeare dramaturg - poet - gânditor.” My translation. 


\section{A comparative survey of bawdy wordplay translations in three Shakespeare editions}

In following the research trajectory set out in the previous subsection, I will now proceed to expanding the quantitative study to include other renditions that may help to substantiate or provide further nuance to the link between translation outcomes and their socio-political background. To eliminate any proportional disadvantage between the three Romanian Shakespeare projects, only those plays that were rendered thrice, once for each complete works collection, were submitted for analysis - Two Gentlemen of Verona, The Taming of the Shrew, Merry Wives of Windsor, Henry V, Othello, King Lear, The Tempest, The Winter's Tale, and Hamlet. By doing so, the numerical disproportionality between Protopopescu's translations, of which only nine are still available nowadays to the wider public, and the 'ESPLA' edition/the latest Shakespeare edition is eliminated. Since 'Univers' coincides, in what concerns said plays, with its precursor in all but one respect, Levițchi's rendition of Hamlet, it does not feature in the study below. It is, however, compared with it in a later subsection devoted to the communist Shakespeare editions. Figure 2 charts the distribution of the 177 instances of bawdy wordplay identified in said nine plays across the translation strategies deployed to render them for the three main Shakespeare collections: Protopopescu's, 'ESPLA', and Volceanov's 'Shakespeare for the Third Millennium'.

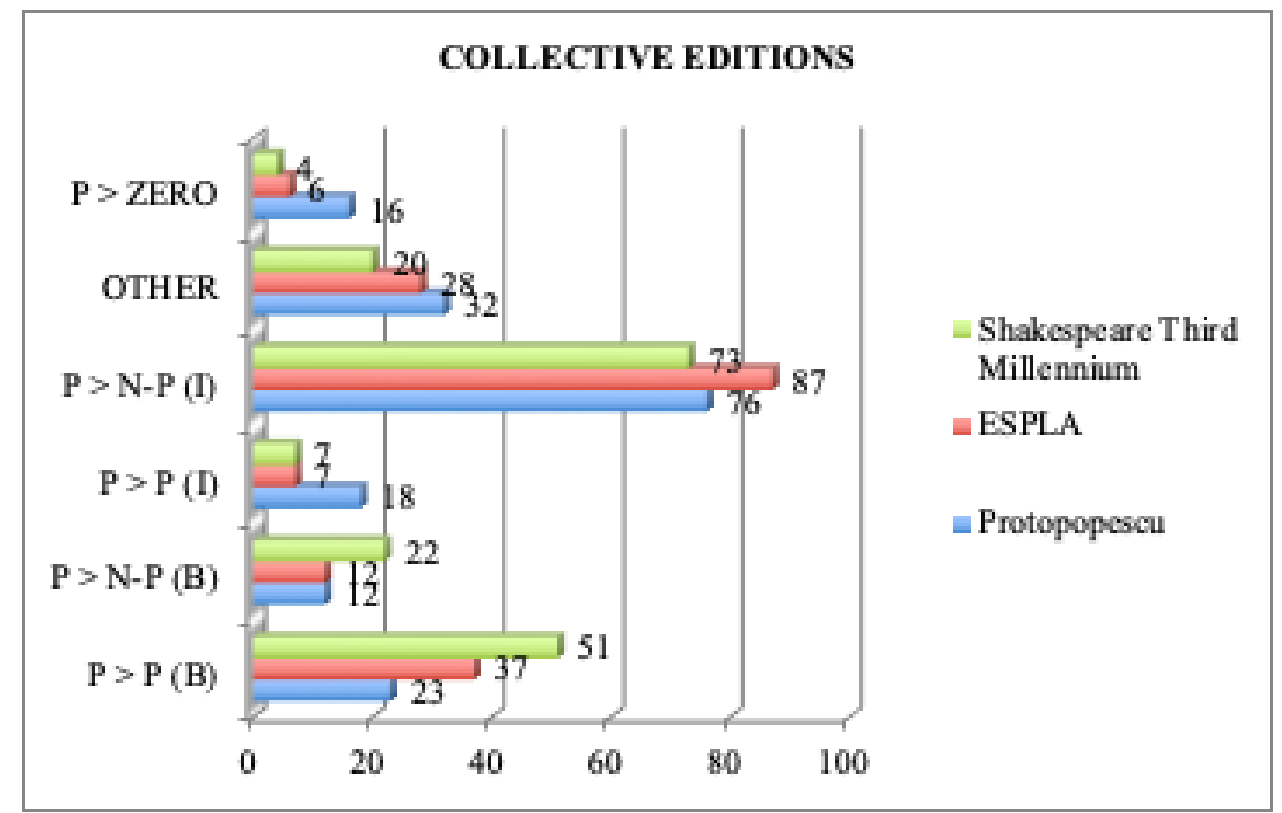

Figure 2. Translation strategies in Protopopescu's Shakespeare edition, 'ESPLA', and the 'Shakespeare for the Third Millennium' project 
It has been noted that, from Protopopescu's Hamlet, no less than four ribald puns of the total twelve completely disappear. Since their contexts also vanish from his translation, these omissions cannot be attributed to the low semantic relevance of said instances of wordplay. Upon investigating the remainder of Protopopescu's renditions, more other such deletions have emerged. In fact, of the 166 obscene puns identified in the aforementioned additional eight Shakespearean plays, 12 others have also been eliminated from his translations. Thus, the sum total of missing wordplay from Protopopescu's renditions outnumbers the 'ESPLA' and 'Shakespeare for the Third Millennium' [henceforth referred to by its coordinator's name, Volceanov] editions.

What further distinguishes his translations from those produced within 'ESPLA' and Volceanov's collection is, unsurprisingly, the fewer instances of wordplay that survived translation both in terms of punning and bawdiness. Specifically, while the two succeeding editions both amount to seven innocent puns each, Protopopescu's renditions amass four puns more than their double. This finding appears to indicate that, in many a case, the translator was aware of the existence of the wordplay, yet willfully decided to eliminate their bawdy substratum. Also, the ribald wordplay whose translation strategies fall, in his renditions, under the PUN > PUN BAWDY, PUN > NON-PUN BAWDY, PUN > PUN INNOCENT, and OTHER classes of pun translation strategies parallel those in 'ESPLA'. This reinforces the probability that Protopopescu was self-preserving rather than underinformed on the topic of the dramatist's bawdy.

As tentatively suggested in the previous subsection, the 'ESPLA' 1955-1963 collection appears once again to indicate definite progress in terms of obscene pun translation. The wordplay translated both bawdily and punningly or suggestively outnumbers Protopopescu's only by almost fifteen cases. Conversely, the 'ESPLA' edition features the highest occurrence of wordplay translated neither punningly nor ribaldly. Volceanov's edition, on the other hand, records a decrease in all the strategies associated with a greater or lesser degree of loss in punning and ribaldry [see P > ZERO, OTHER, P > N-P (I)] and an increase in the number of puns translated via the PUN > PUN BAWDY and PUN > NON-PUN BAWDY strategies. Figure 2 also reveals a higher occurrence of wordplay recreated both punningly and bawdily, which shows that the apparent shift in focus from language-play toward 
ribaldry witnessed in Hamlet does not hold true when multiple renditions within this project are analyzed.

\section{The rendition of Shakespeare's bawdy wordplay in the pre-communist period}

What follows is a comparative survey of how the earliest three most prolific translators of the dramatist's plays tackled his bawdy wordplay. Since the number of plays translated by Scarlat Ion Ghica, Dimitrie Ion Ghica, and Adolphe Stern varies widely, I decided to group together the translation methods utilized by the Ghica brothers. Petre Grimm (333) and Monica Matei-Chesnoiu (58-59) adopt a similar approach, in that they review their renditions jointly. In addressing the fact that there are only two plays translated by both one of the Ghica brothers and Stern Merchant of Venice and Julius Caesar - and that drama texts rendered by the former contain fifteen more puns than those Stern translated, I have converted the occurrences of each rendition strategy to percentages, as is evident from Figure 3.

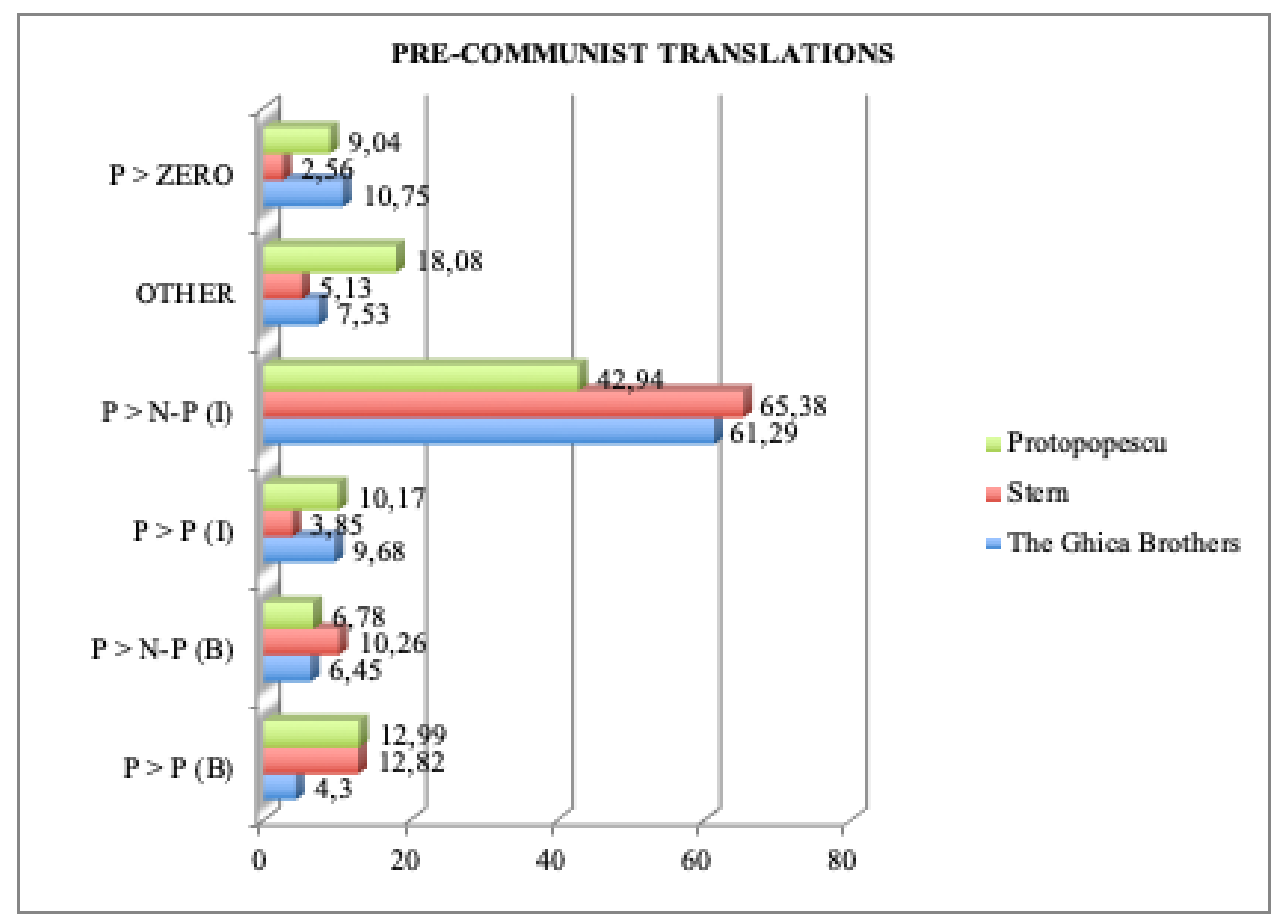

Figure 3. Pun translation strategies in the Ghica brothers', Stern's, and Protopopescu's renditions

Romanian scholars have written laudatorily of the Ghicas' translations of Shakespeare, commenting on how they are "carefully produced, superior to all others 
before them" (Grimm 333)33 and Ioan S. Ghica's "translation [of King John] is more accurate and stylistically valid than it is reasonable to expect from such early versions" (Matei-Chesnoiu 60). Conversely, Stern's renditions, the earliest of which Hamlet, Julius Caesar, and King Lear - were released around the same time as the Ghicas', appear to have not generated an equally eulogistic critical response.

Contemporary scholars such as Iancu Botez and Alexandru D. Xenopol devote page-long studies to Stern's errors, archaized language, and obstinate faithfulness to the source text, with some putting forward a harsher critique than others. The common denominator between their articles is, as reiterated by Petre Grimm, that "Stern produces not only errors of the Romanian language, using words the meanings of which he does not understand, but also of grammar, in addition to his misinterpretations of the English text” (352)34. Daniela M. Marțole goes on to argue how their criticism fueled right-wing Moldovan politician Alexandru C. Cuza's tirade against Stern's translations, whose shortcomings he perceives as stemming from "a racial cultural sterility, an incapacity derived from the lack of a Jewish homeland that should shelter the creative power of their nationality" (qtd. in Marțole 44).

In terms of bawdy pun translation, however, Stern fares surprisingly well against other more qualified translators such as Protopopescu. Of the 177 puns featured in Protopopescu's translations, 23 qualify for the PUN > PUN BAWDY strategy. Conversely, Stern's source texts contain fewer puns, namely 78, yet the translator resorts to this translation solution in a similar percentage of cases to Protopopescu. In turn, the Ghicas deploy it for only $4.3 \%$ of the ribald puns occurring in the plays they translated. As for the cases in which only the suggestive subtext survives translation, Stern ranks higher than both the Ghicas and Protopopescu, with the instances qualifying for the PUN > NON-PUN BAWDY method reaching 10.26\%. The three other translators stand at similar percentage levels, namely $6.45 \%$ and $6.78 \%$ respectively.

With regard to the potentially expurgatory PUN > ZERO, Stern fares better than the Ghicas and Protopopescu. Specifically, Protopopescu resorts to seven omissions, while the Ghicas and Stern to five and two respectively. The fact that Stern, a Jewish-Romanian lawyer, recreated roughly as many ribald puns as

33 "sânt făcute conștiincios, sânt superioare tuturor celor anterioare." My translation.

34 “d. Stern face nu numai greșeli de limbă românească și de întrebuințarea cuvintelor, ale căror nuanțe de înțeles nu le cunoaște, chiar și de gramatică, pe lângă greșeli de interpretare a textului englez." My translation. 
Protopopescu, a Professor of English, did almost sixty years later, is indicative of the former's familiarity with Shakespeare's ribald puns and vocabulary, which then critics overlook due to his Jewish origins and lack of formal training, while the higher frequency of PUN > ZERO renditions in the latter's translations points once again to the existence of negative translator-subjective and objective influences in his case.

\section{The rendition of Shakespeare's bawdy wordplay in the communist period}

In the quantitative analysis of Hamlet, it has been shown how Levițchi and Duțescu's re-translation of Hamlet fares better than Vinea's in terms of successful bawdy pun translation, while the latter surpasses the co-translators' cumulatively, when the instances of wordplay translated via the PUN > NON-PUN BAWDY, and OTHER strategies are also taken into consideration. The close competition between the two renditions of this Shakespearean play has raised the question of whether the retranslations of other dramatic texts hold the key to ascertaining which of the two communist editions of the dramatist's works maintains a higher level of faithfulness to the Bard's bawdy puns. Since 'ESPLA' and 'Univers' overlap in many cases, a chart was generated based on those plays that were re-rendered for the latter project. What resulted is Figure 4, which compares the 'ESPLA' translation of the ribald puns in Measure for Measure, Antony and Cleopatra, Hamlet, Midsummer Night's Dream, Richard III, Romeo and Juliet, The Merchant of Venice, and Cymbeline with their re-renditions in 'Univers'.

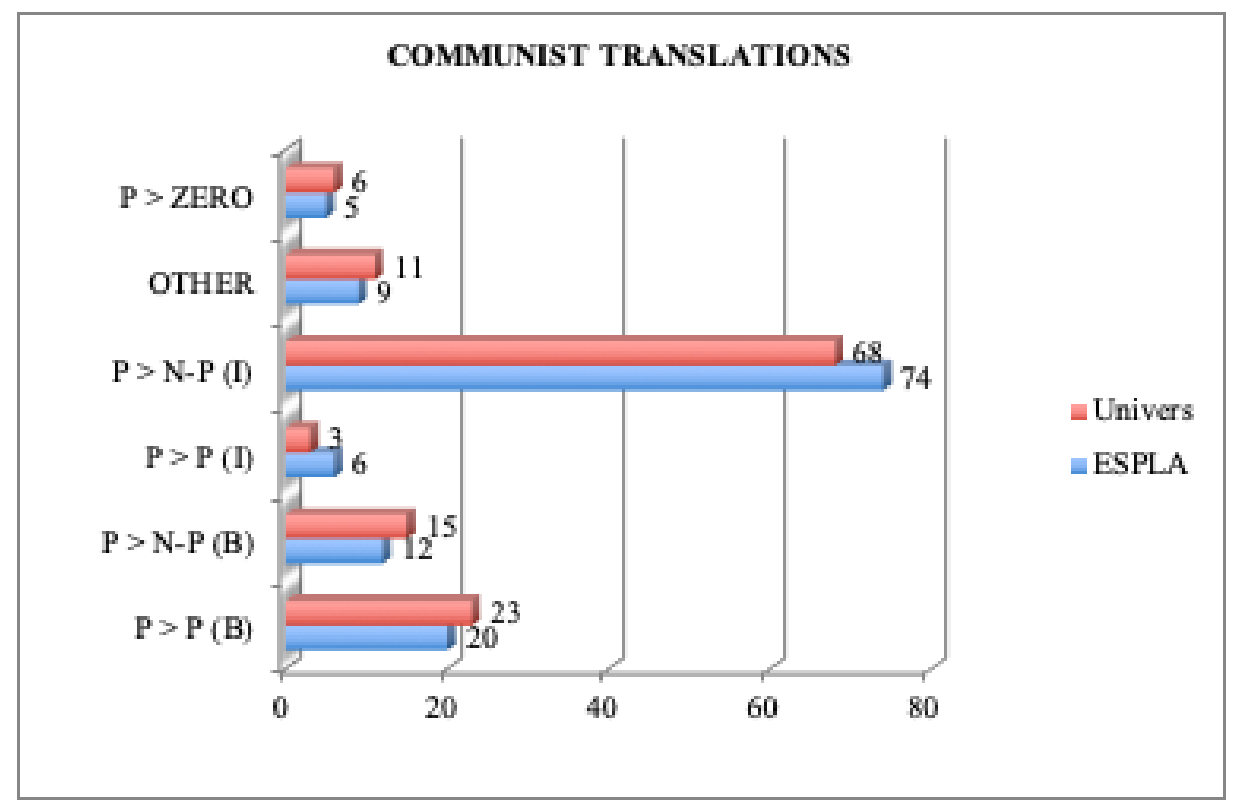

Figure 4. Pun translation strategies in the 'ESPLA' and 'Univers' editions of Shakespeare 
The difference between the two is not especially pronounced in terms of full or partial reproduction of ribald wordplay, a phenomenon also witnessed in the case of their translation of bawdy Hamletian puns: 'ESPLA' comprises 23 instances of language-play effectively recreated in the target language, while 'Univers' contains 20 such specimens. As for the other translation methods, whereby the bawdy only is reproduced, the latter's re-translations amass 15 cases in which the PUN > NONPUN BAWDY technique was deployed, whereas the 'ESPLA' renditions amount to 12 such instances.

As for the compensational translation strategies, 'Univers' appears to lean more toward suggesting the existence of a secondary ribald meaning, which is evident from its higher incidence puns rendered via OTHER strategies. Conversely, 'ESPLA' features more instances of wordplay reproduced punningly, yet non-bawdily in the target language [see $\mathrm{P}>\mathrm{P}(\mathrm{I})$ ].

The observable progress 'Univers' records as compared to 'ESPLA' is congruent with Milică's theory of the paradoxical relaxation of the censorship's grip amidst the latter part of Nicolae Ceauşescu's regime (33-34), yet it is not sufficiently large to demonstrate beyond reasonable doubt whether a negative external force affected the preceding edition.

\section{The rendition of Shakespeare's bawdy wordplay in the post-communist period}

In order to identify the similarities and differences between modern renditions produced individually and within a translation project, four plays - Romeo and Juliet, Hamlet, Othello, and Macbeth - were singled out. The only criterion deployed in selecting these texts was that of having been translated by the two most prolific contemporary translators of Shakespeare's plays - Dan A. Lăzărescu and Nicolae Ionel - and one of the translators involved in Volceanov's translation project. In theory, their translators enjoyed equal access to supplementary critical materials devoted to Shakespeare's bawdy wordplay and a comparably hospitable sociopolitical background. This analysis endeavors to uncover whether these factors were conducive to a similar distribution of the 92 bawdy puns rendered by all the three translators across the competence model. For this purpose, Figure 5 was generated. 


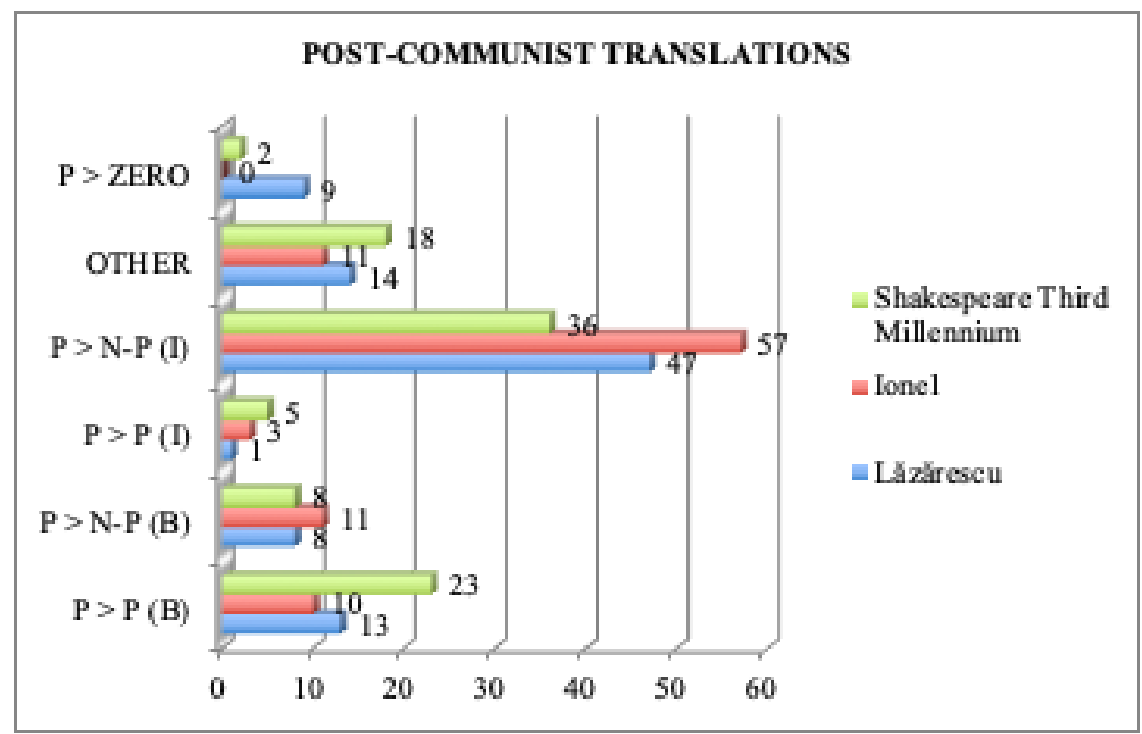

Figure 5. Pun translation strategies in the 'Shakespeare for the Third Millennium' project and Lăzărescu's and Ionel's renditions

Not only does the chart reveal a heterogeneous dissemination of the corpus among the six translation strategies, but it also illustrates a wider discrepancy between the surveyed renditions than in any of the previous graphs. The translators involved in Volceanov's project recreate double the number of puns Lăzărescu and Ionel reproduce in their renditions of the same plays. Nicolae Ionel, on the other hand, is at once the translator whose renditions display no instance of expurgation and the highest incidence of wordplay translated neither punningly nor bawdily [see P > ZERO and P > N-P (I)]. Similarly, Lăzărescu's translations feature the second largest number of puns effectively recreated and the highest frequency of source-text wordplay to disappear from the target texts.

These findings indicate that a comparable level of access to and availability of studies devoted to the topic does not automatically lead to uniform translation outcomes in the case of translators operating at a similar point in time. In fact, it would not be too far-fetched to say that they confirm a precaution taken before carrying out this study: the more dictionaries and glossaries are released on the topic, the more difficult it is to distinguish between source-text puns of Shakespeare's making or the lexicographer's. 


\section{Conclusions}

Some of the observations that follow from these graphs are only natural: there is an upward trend toward faithfulness to Shakespeare's language-play and/or bawdy that correlates with the availability of and access to studies dedicated to this instance of Shakespearean language use. Other findings invalidate commonly held beliefs among Shakespeare scholars: Protopopescu's edition of Shakespeare's plays, presumed to be 'modernizing' and therefore one of the most successful in retaining, at the very least, a positive bawdy balance, contains the highest number of cases of expurgation, while the 'ESPLA' collection, produced during the most vigilant period of the communist censorship program, exhibits a surprisingly large incidence of puns translated bawdily into Romanian. The former phenomenon is posited to be due to the hunt for pornography in literature led by Romanian academician and scholar Nicolae Iorga, while the latter could be attributed to the lack of censorship intervention (Volceanov 120). Jewish-Romanian lawyer Adolphe Stern, critically deemed one of the least gifted early Romanian translator of Shakespeare's plays, fares better in terms of bawdy and/or wordplay reproduction than Scarlat I. Ghica and Dimitrie I. Ghica, two of the most prolific and highly acclaimed translators of his period. This finding comes to substantiate Daniela M. Marțole's theory according to which the critique of Stern's renditions was affected by some level of ethnic bias. The comparative analysis of the translations produced within the latest Shakespeare project and other individual renditions produced around the same time, expected to yield the most uniform distribution of target-text pun equivalents across the surveyed translation strategies, actually exhibited the least homogenous dispersal, which indicates that a similar level of access to and availability of additional critical resources does not automatically generate equally effective pun renditions.

Through these results, the present study on the translation of Shakespeare's bawdy wordplay into Romanian complements and enhances existing research on the topic in the following ways: (a) it is the first attempt at charting Romanian translational attitudes toward the dramatist's ribald puns; (b) it rests on a comprehensive corpus of 325 source-text bawdy puns derived from 20 Shakespearean plays and 71 Romanian renditions; (c) it puts forward an updated quantitative studies-oriented methodology, which combines Dirk Delabastita's authoritative competence model and its cognitive-pragmatic reworking by Francisco Javier Díaz-Pérez; (d) it links translational approaches to Shakespeare's ribald 
wordplay to translator-subjective and objective factors, ranging from their personal background to the ideological backdrop of their period; (e) it provides a series of compelling comparative analyses between the four available Romanian editions of Shakespeare's works and in relation to other individual translations produced in the same chronological periods.

\section{References:}

Cinpoeş, Nicoleta. “The Born-again Socialist Bard: Hamlet in Romania.” The Hamlet Zone: Reworking Hamlet for European Cultures, edited by Ruth J. Owen. Cambridge Scholars Publishing, 2012: 91-104.

Cordoş, Sanda. Ion Vinea: un scriitor între lumi şi istorii. Editura Şcoala Ardeleană, 2017.

Delabastita, Dirk. There's a Double Tongue: An Investigation into the Translation of Shakespeare's Wordplay. Rodopi, 1993.

Díaz-Pérez, Francisco Javier. "From the Other Side of the Looking Glass: A Cognitive-Pragmatic Account of Translating Lewis Carroll." Yearbook of Corpus Linguistics and Pragmatics 2015: Current Approaches to Discourse and Translation Studies, edited by Jesús Romero-Trillo, Springer, 2015: 163194.

---. "The Translation of Wordplay from the Perspective of Relevance Theory: Translating Sexual Puns in two Shakespearian Tragedies into Galician and Spanish.” Meta, vol. 58, no. 2, 2013: 279-302.

Erne, Lukas. Shakespeare as Literary Dramatist. Cambridge UP, 2003.

Grimm, Petre. “Traduceri şi imitaţiuni româneşti după literatura engleză.” Dacoromania, vol. 3, 1924: 284-377.

Krawiec, Magdalena. "Shakespeare in Polish. On Puns and Translation Strategies in Love's Labour's Lost'. SKASE Journal of Translation and Interpretation, vol. 11, no. 1, 2017: 106-127.

Martin, Anca-Simina. "Foreignizing Shakespeare's Bawdy Multilingual Puns in Communist and Post-Communist Romania." The Culture of Translation in Romania/ Übersetzungskultur und Literaturübersetzen in Rumänien, edited by Maria Sass, Ștefan Baghiu, and Vlad Pojoga. Peter Lang, 2018: 175-187. 
Marțole, Daniela Maria. "Ethnic Bias in the Reception of Adolphe Stern's Translations of Hamlet and Macbeth." Messages, Sages and Ages, vol. 2, no. 1, 2015: 38-46.

Matei-Chesnoiu, Monica. Shakespeare in the Romanian Cultural Memory. Fairleigh Dickinson UP, 2006.

Milică, Iulia Andreea. "William Shakespeare in Communist Romania”. Tradução em Revista. vol. 12, no. 1, 2012: 18-38.

Nicolaescu, Mădălina. "Translations of Shakespeare in Romania-Going from Local to Global?” Perspectives: Studies in Translatology. 20.3, 2012: 285-296.

Partridge, Eric. Shakespeare's Bawdy. 3rd ed., Routledge by Taylor \& Francis Group, 2011.

Rubinstein, Frankie. A Dictionary of Shakespeare's Sexual Puns and Their Significance. 2nd ed., Macmillan P, 1989.

Sato, Eriko. 2019. "A translation-based heterolingual pun and translanguaging." Target, vol. 31, no. 1, https://doi.org/10.1075/target.18115.sat.

Shakespeare, William. A Midsummer Night's Dream. Edited by Jonathan Bate \& Eric Rasmussen. Macmillan Publishers Ltd., 2008.

---. Antoniu şi Cleopatra. Translated by Adolphe Stern. Contemporary Literature P, 2016 [1922].

---. Antoniu și Cleopatra. Translated by Leon Levițchi. Opere complete 7. Univers, 1988.

---. Antoniu şi Cleopatra. Translated by Scarlat Ghica I. Contemporary Literature P, 2016 [1893].

---. Antoniu şi Cleopatra. Translated by Tudor Vianu. Opere complete 9. Editura de stat pentru literatură și artă, 1961.

---Antony and Cleopatra. Edited by Jonathan Bate \& Eric Rasmussen. Macmillan Publishers Ltd., 2009.

---. Cei doi tineri din Verona. Translated by Mihnea Gheorghiu. Opere complete 2. Univers, 1983.

---. Coriolan. Translated by Adolphe Stern. Opere alese II. Editura Librăriei Socec, 1922.

---. Coriolanus. Edited by Jonathan Bate \& Eric Rasmussen. Macmillan Publishers Ltd., 2011. 
---. Cymbeline. Edited by Jonathan Bate \& Eric Rasmussen. Macmillan Publishers Ltd., 2011

---. Cymbeline. Translated by Leon Levițchi. Opere complete 8. Univers, 1990.

---. Cymbeline. Translated by Nicolae Argintescu-Amza. Opere complete 11. Editura de stat pentru literatură și artă, 1963.

---. Doi domni din Verona. Translated by Dragoș Protopopescu. Fundația regală pentru literatură și artă, 1944.

---. Doi tineri din Verona. Translated by Lucia Verona. Opere VI. Tracus Arte, 2013.

---. După faptă și răsplată. Translated by Nicoale Argintescu-Amza. Opere complete 9. Editura de stat pentru literatură și artă, 1961.

---. Furtuna. Translated by Dragoș Protopopescu. Fundaţia pentru literatură și artă “Regele Carol II", 1940.

---. Furtuna. Translated by George Volceanov. Opere I. Paralela 45, 2010.

---. Furtuna. Translated by Leon Levițchi. Opere complete 11. Editura de stat pentru literatură și artă, 1963.

---. Hamlet. Edited by Jonathan Bate \& Eric Rasmussen. Macmillan Publishers Ltd., 2008.

---. Hamlet. Translated by Adolphe Stern. Contemporary Literature P, 2016 [1877].

---. Hamlet. Translated by Dan A. Lăzărescu. Pandora-M, 2009.

---. Hamlet. Translated by Dragoș Protopopescu. Fundația pentru literatură și artă “Regele Carol II”, 1938.

---. Hamlet. Translated by Leon Levițchi and Dan Duțescu. Opere complete 5 . Univers, 1986.

---. Hamlet. Translated by Nicolae Ionel. 12 Tragedï. Tehnopress, 2016.

---. Hamlet. Translated by Petru Dumitru. (Vinea, Ion). Opere complete 7. Editura de stat pentru literatură și artă, 1959.

---. Hamlet. Translated by Ştefan Runcu. (Aurora Cornu). Biblioteca pentru toți, 1962.

---. Hamlet. Translated by Vera Călin and Maria Banuş. Editura de stat, 1948.

---. Hamlet. Translated by Victor Anestin. Contemporary Literature P, 2019 [1908].

---. Hamlet. Translated by Violeta Popa and George Volceanov. Opere II. Pitești: Paralela 45, 2010.

---. Hamlet. Translated by Vladimir Streinu. Thalia, 1970. 
---. Henric al V-lea. Translated by Dragoș Protopopescu. Fundația regală pentru literatură și artă, 1940.

---. Henric al V-lea. Translated by Horia Gârbea. Opere XII. Tracus Arte, 2017.

---. Henric al V-lea. Translated by Ion Vinea. Opere complete 4. Univers, 1985.

---. Henry V. Edited by Jonathan Bate \& Eric Rasmussen. Macmillan Publishers Ltd., 2010.

---. Imblânzirea scorpiei. Translated by Dan A. Lăzărescu. Opere complete 4. Editura de stat pentru literatură și artă, 1957.

---. Imblânzirea scorpiei. Translated by Violeta Popa. Opere IV. Pitești: Paralela 45, 2011.

---. Iuliu Cesar. Translated by Adolphe Stern. Contemporary Literature P, 2016 [1879].

---. Iulius Cesar. Translated by Adolphe Stern. Opere alese II. Editura Librăriei Socec, 1922.

---. Julius Caesar. Edited by Jonathan Bate \& Eric Rasmussen. Macmillan Publishers Ltd., 2011.

---. Julius Cesar. Translated by Scarlat Ghica I. Contemporary Literature P, 2016 [1896].

---. King John and Henry VIII. Edited by Jonathan Bate \& Eric Rasmussen. Macmillan Publishers Ltd., 2012.

---. King Lear. Edited by Jonathan Bate \& Eric Rasmussen. Macmillan Publishers Ltd., 2009.

---. Macbeth. Edited by Jonathan Bate \& Eric Rasmussen. Macmillan Publishers Ltd., 2009.

---. Macbeth. Translated by Adolphe Stern. Cultura Națională, 1922.

---. Macbeth. Translated by Dan A. Lăzărescu. Pandora-M, 2016.

---. Macbeth. Translated by Horia Gârbea. Opere IX. Tracus Arte, 2014.

---. Macbeth. Translated by Nicolae Ionel. 12 Tragedii. . Tehnopress, 2016.

---. Măsură pentru măsură. Translated by Leon Levițchi. Opere complete 6. Univers, 1987.

---. Measure for Measure. Edited by Jonathan Bate \& Eric Rasmussen. Macmillan Publishers Ltd., 2010.

---. Negustorul din Veneția. Translated by Adolphe Stern. Cultura Națională, 1923. 
---. Neguțătorul din Veneția. Translated by Scarlat Ghica I. Contemporary Literature P, 2016 [1885].

---. Neguțătorul din Veneția. Translated by Gala Galaction. Opere complete 2. Editura de stat pentru literatură și artă, 1955.

---. Neguțătorul din Veneția. Translated by Petre Solomon. Opere complete. Vol. 3. Univers, 1984.

---. Nevestele vesele din Windsor. Translated by Vlaicu Bîrna. Opere 5. Editura de stat pentru literatură și artă, 1958.

---. Nevestele vesele din Windsor. Translated by Dragoș Protopopescu. Biblioteca pentru toți, 1943.

---. Nevestele vesele din Windsor. Translated by George Volceanov and Adriana Volceanov. Opere III. Paralela 45, 2010.

---. Othello. Edited by Jonathan Bate \& Eric Rasmussen. Macmillan Publishers Ltd., 2009.

---. Othello. Translated by Dan A. Lăzărescu. Pandora-M, 2016 [2006].

---. Othello. Translated by Horia Gârbea. Opere X. Tracus Arte, 2015.

---. Othello. Translated by Ion Vinea. Opere complete 6. Univers, 1987.

---. Othello. Translated by Nicolae Ionel. 12 Tragedii. Tehnopress, 2016.

---. Poveste de iarnă. Translated by Dan Grigorescu. Opere complete 11. Editura de stat pentru literatură și artă, 1963.

---. Poveste de iarnă. Translated by Dragoș Protopopescu. Fundația regală pentru literatură și artă, 1942.

---. Poveste de iarnă. Translated by Violeta Popa. Opere VIII. Tracus Arte, 2014.

---. Regele Ioan. Translated by Scarlat Ghica I. Contemporary Literature P, 2016 [1892].

---. Regele Lear. Translated by Adolphe Stern. Contemporary Literature P, 2016 [1881].

---. Regele Lear. Translated by Dragoș Protopopescu. Fundaţia regală pentru literatură și artă, 1942.

---. Regele Lear. Translated by George Volceanov. Opere XIV. Tracus Arte, 2018.

---. Regele Lear. Translated by Mihnea Gheorghiu. Opere complete 7. Univers, 1988.

---. Richard al III-lea. Translated by Dan Duțescu. Opere complete 1. Univers, 1982.

---. Richard al III-lea. Translated by Florian Nicolau. Opere complete 7. Editura de stat pentru literatură și artă, 1958. 
---. Richard III. Edited by Jonathan Bate \& Eric Rasmussen. Macmillan Publishers Ltd., 2008.

---. Romeo and Juliet. Edited by Jonathan Bate \& Eric Rasmussen. Macmillan Publishers Ltd., 2009.

---. Romeo şi Giulieta. Translated by Nicolae Ionel. 12 Tragedii. Tehnopress, 2016.

---. Romeo şi Julieta. Translated by Al. Philippide. [Şt. O. Iosif]. Opere complete 1. Editura de stat pentru literatură și artă, 1960.

---. Romeo şi Julieta. Translated by Anca Ignat and Alexandru M. Călin. Opere XIII. Tracus Arte, 2018.

---. Romeo şi Julieta. Translated by Dan A. Lăzărescu. [Şt. O. Iosif]. Pandora-M, 2009.

---. Romeo și Julieta. Translated by Dimitrie Ghica I. Contemporary Literature P, 2016 [1882].

---. Romeo și Julieta. Translated by Virgil Teodorescu. Opere complete 3. Univers, 1984.

---. Scorpia îmblânzită. Translated by Dragoș Protopopescu. Fundația regală pentru literatură şi artă, 1943.

---. The Merchant of Venice. Edited by Jonathan Bate \& Eric Rasmussen. Macmillan Publishers Ltd., 2012.

---. The Merry Wives of Windsor. Edited by Jonathan Bate \& Eric Rasmussen. Macmillan Publishers Ltd., 2011.

---. The Taming of the Shrew. Edited by Jonathan Bate \& Eric Rasmussen. Macmillan Publishers Ltd., 2010.

---. The Tempest. Edited by Jonathan Bate \& Eric Rasmussen. Macmillan Publishers Ltd., 2008.

---. The Two Gentlemen of Verona. Edited by Jonathan Bate \& Eric Rasmussen. Macmillan Publishers Ltd., 2011.

---. The Winter's Tale. Edited by Jonathan Bate \& Eric Rasmussen. Macmillan Publishers Ltd., 2009.

---. Tragedia lui Othello. Translated by Dragoș Protopopescu. Fundația regală pentru literatură și artă, 1948.

---. Viaţa și moartea regelui Richard III. Translated by Scarlat Ghica I. Contemporary Literature P, 2016 [1884]. 
---. Viața şi moartea regelui Richard III. Translated by Scarlat Ghica I. Contemporary Literature P, 2016 [1892].

---. Visul unei nopți de vară. Translated by Dan Grigorescu. Opere complete 3. Univers, 1984.

---. Visul unei nopți de vară. Translated by Florin Tornea. [Șt. O. Iosif]. Opere complete 3. Editura de stat pentru literatură și artă, 1956.

Terian, Andrei. Critica de export. Editura Muzeul Național al Literaturii Române, 2013.

Volceanov, George. "Appropriating Through Translation: Shakespeare Translations in Communist Romania." Translation Studies: Retrospective and Prospective Views. Conferinţa internaţională "Studii de traducere - retrospectivă și perspective," 16-17 June, 2006, edited by Floriana Popescu, Dunărea de Jos University of Galați, 2006: 138-145.

---. "Bowdlerizing Shakespeare: Here, There, and Everywhere." B.A.S British and American Studies, vol. 1, no. 11, 2005: 117-130.

---. "On Shakespeare's Bawdy and Its Translation into Romanian.” Argotica. vol. 1, no. 1, 2012: 216-232.

Wells, Stanley. Looking for Sex in Shakespeare. Cambridge UP, 2004. 